\title{
The Link between Food Security and Life Satisfaction: Panel Data Analysis
}

\author{
Raufhon Salahodjaev * and Ziroat Mirziyoyeva
}

check for updates

Citation: Salahodjaev, R.;

Mirziyoyeva, $Z$. The Link between Food Security and Life Satisfaction: Panel Data Analysis. Sustainability 2021, 13, 2918. https://doi.org/ $10.3390 /$ su13052918

Academic Editor:

Francisco Pedrero Salcedo

Received: 31 January 2021

Accepted: 3 March 2021

Published: 8 March 2021

Publisher's Note: MDPI stays neutral with regard to jurisdictional claims in published maps and institutional affiliations.

Copyright: (c) 2021 by the authors. Licensee MDPI, Basel, Switzerland. This article is an open access article distributed under the terms and conditions of the Creative Commons Attribution (CC BY) license (https:/ / creativecommons.org/licenses/by/ $4.0 /)$.
Tashkent Institute of Irrigation and Agricultural Mechanization Engineers, 39 Kari Niyazov Street, Tashkent 100000, Uzbekistan; zhmresearch@gmail.com

* Correspondence: salahodjaev@gmail.com; Tel.: +998-97-713-3922
Abstract: The goal of this study is to explore the causal relationship between food (in)security and life satisfaction in a global setting. We explore this relationship using conventional ordinary least squares (OLS) regression and instrumental variable two-stage least squares (IV 2SLS) method. Using data from 105 countries over the period 2012-2019, we found that food insecurity is significantly and negatively related to life satisfaction. The results are robust even after controlling for GDP growth, government size, quality of political and legal institutions. In addition, by adopting natural disaster data, we show that food insecurity has causal negative effect on life satisfaction. In particular, a one standard deviation increase in instrumented food insecurity decreases life satisfaction by 0.8 points (slightly less than one standard deviation). The results remain robust for a series of tests. Future studies should extend our findings by exploring the role of food security in other measures of quality of life.

Keywords: subjective well-being; food security; life satisfaction; natural disasters; causality; panel data

\section{Introduction}

According to FAO et al. (2020), nearly 690 million people (almost 9\% of world's population) suffer from starvation. Apart from this, an increasing number of people are forced to decrease the quantity and quality of the food they eat. More than 2 billion people (or $26 \%$ of the world's population) face food insecurity (hunger) or do not have daily access to nutritious and sufficient food. As a result, the empirical research on various aspects of food (in)security, including causes and consequences, has grown considerably in size. Indeed, a large strand of studies investigates the driving forces of food (in)security. These studies show that climate change [1], natural disasters [2], instability in food production [3], poverty [4] and land resources [5] are among variables related to food (in)security.

Extant research shows that food insecurity may have various implications for society as it has been linked to conflicts [6], migration [7] and terrorism [8]. For example, Smith and Floro [9], using data from 94 low- and middle-income countries surveyed by Gallup World Poll, covering more than 135,000 individuals, show that food insecurity is an important antecedent of migration intentions even after controlling for socio-economic factors.

In addition, while there is growing evidence that food (in)security is related to qualityof-life proxies such as suicide attempts [10], well-being [11] and depression [12], previous studies largely overlook the question if food insecurity is among predictors of life satisfaction. Happiness or life satisfaction is a paramount human sentiment and most individuals appraise life satisfaction above financial assets [13]. This paper is aimed to fill in the existing empirical research gap by investigating the relationship between food security and life satisfaction using cross-country data.

Due to the lack of data, research investigating the role that food (in)security plays in explaining life satisfaction, mostly focused on specific demographic groups within a single country such as aboriginal population [14], youth [15] or rural population [16]. A number of separate studies have explored the effect of food security on mental health and well-being in 
developed and developing countries [17-19]. These studies suggest that depression levels are higher in households that are food insecure. For example, two separate papers from the USA $[20,21]$ found that food insecurity is significantly and positively related to poor mental health. In another study based on households from low-income populations [22], the authors found that families associated with lower levels of food security report higher levels of depression. However, due to the cross-sectional nature of the data and a small sample size, it is impossible to identify the direction of the causal relationship.

On the other hand, there are significant differences in the design of related studies, as well as in the assessment techniques adopted to measure food insecurity and life satisfaction. Consequently, it is uncertain if discovered association will robustly hold across different countries and time periods. Thus, validating stability and consistency of the link between food insecurity and life satisfaction across nations would shed additional light on the growing literature on cross-country determinants of life satisfaction by suggesting another potential antecedent. To the best of our knowledge, Frongillo et al. [23] is the only published paper that investigates the association between food security and life satisfaction, using data from 138 countries for the year 2014.

The explicit aims of this study are (1) to investigate the link between food security and life satisfaction at a macro-social level across all countries, and (2) assess the causality of this relationship. In particular, to reach this aim, we explore the relationship between food (in)security and life satisfaction in a sample of 105 countries over the period 2012-2019. We rely on conventional ordinary least squares (OLS) regression and instrumental variable twostage least squares (IV 2SLS) method. Our results show that food insecurity is significantly and negatively related to life satisfaction. The results are robust, even after controlling for GDP growth, government size, quality of political and legal institutions, time and region fixed effects. In addition, using the number of total people affected by natural disaster and the total value of all damages and economic losses as instruments for food insecurity, we show that food security has causal impact on life satisfaction. In particular, a one standard deviation increase in the share of people affected by natural disasters reduces life satisfaction by 0.8 points (slightly less than one standard deviation). The results remain robust for a series of tests. Future studies should extend our findings by exploring the role of food security in other measures of quality of life.

\section{Data and Methods}

There is ongoing debate in scholarly literature on the type of measures of subjective well-being [24]. While some studies rely on affective experience measures [25], one of the most widely used measures in the empirical literature is self-reported life satisfaction, the validity of which was confirmed by a number of studies $[26,27]$. As suggested by Dolan and Metcalfe [28], "Most of the recent attempts at measuring SWB have focused on providing information that can be used as inputs into monitoring progress ... [moving] move us away from focusing on the "ill-being" reflected in rates of depression towards more positive notions of life satisfaction" (p. 413). Therefore, the dependent variable in this study is the life satisfaction index obtained from the Cantril ladder question that invites survey participants to imagine their current position on a ladder with steps numbered from 0 to 10 , where the top represents the best possible life for themselves and the bottom represents the worst possible life for themselves. The data are collected by Gallup world poll and extracted from World Happiness Report [29]. We use this measure of life satisfaction, as it is available for a larger sample of countries and collected on an annual basis, allowing us to maximize the sample size.

Measuring food insecurity is a complex and challenging task. In scholarly research, studies rely on various proxies that capture diverse dimensions of food insecurity, such as food spending patterns, past household consumption or coping strategy index [30]. In addition, food security is indirectly proxied by hunger, anthropometric data, undernourishment, caloric intake and others. However, the data for these indicators are not entirely available across time and across countries. Therefore, in our study, our independent vari- 
able is the Food Security Index (FSI). FSI is constructed from 34 unique indicators that measure these drivers of food security across both developing and developed countries and aim to assess the food insecurity across three paramount dimensions, namely affordability, availability and quality/safety. This index has two important advantages: (1) it is collected and estimated for majority countries for a number of years; (2) it captures the multidimensional nature of food security. The data come from the Economist Intelligence Unit and are available only for the period from 2012 to 2019. We reversed the scores so that higher values reflect greater levels of food insecurity.

In addition, in our econometric model we include a set of confounding variables that are shown to be linked to happiness inequality in cross-country empirical research. First, we include GDP growth to capture the role of economic growth in subjective well-being. Extant research shows that income is a robust ingredient of life satisfaction [31]. We also include the Democracy Index from the Polit V project, as there is evidence that democratization may be correlated with subjective well-being [32]. Apart from GDP growth and democratization, following extant research on life satisfaction, we control for government size, proportion of women in parliament, philanthropy rates and corruption, as these variables have been correlated to life satisfaction in cross-country research ([33-35]). The summary statistics for our main variables used in this study are reported in Table 1. For example, the average global level of life satisfaction in our sample is 5.5 points, while the average GDP growth rate is $3.4 \%$. At the same time, mean value of female representation in parliament is $23.2 \%$ and the average global social capital level (proportion of national population that helped strangers) is $48.9 \%$.

Table 1. Summary statistics.

\begin{tabular}{|c|c|c|c|c|c|}
\hline Variable & Description & Mean & Std. Dev. & Min & Max \\
\hline Life satisfaction & $\begin{array}{l}\text { Life satisfaction index } \\
\text { Source: World Happiness Report }\end{array}$ & 5.516 & 1.178 & 2.688 & 7.858 \\
\hline Food insecurity & $\begin{array}{c}\text { Food (in)security } \\
\text { Source: Economist Intelligence Unit }\end{array}$ & 42.301 & 17.643 & 10.5 & 81.6 \\
\hline GDP growth & $\begin{array}{c}\text { GDP growth, \% } \\
\text { Source: World Bank } \\
\end{array}$ & 3.462 & 3.235 & -27.994 & 25.163 \\
\hline Government size & $\begin{array}{l}\text { Government final consumption as \% of GDP } \\
\text { Source: World Bank }\end{array}$ & 15.499 & 5.133 & 3.588 & 30.003 \\
\hline Democracy index & $\begin{array}{l}\text { Democracy index } \\
\text { Source: Polit V project }\end{array}$ & 4.467 & 5.942 & -10 & 10 \\
\hline Women in parliament & $\begin{array}{l}\text { Proportion of women in parliament } \\
\text { Source: World Bank }\end{array}$ & 23.230 & 11.971 & 0 & 63.8 \\
\hline CPI & $\begin{array}{c}\text { Corruption perception index } \\
\text { Source: Transparency International }\end{array}$ & 43.782 & 20.159 & 11 & 92 \\
\hline Social capital & $\begin{array}{l}\text { Proportion of population that helped stranger, \% } \\
\text { Source: KAF foundation }\end{array}$ & 48.931 & 12.737 & 16 & 81 \\
\hline
\end{tabular}

To assess the relationship between food insecurity and life satisfaction, we estimate the following regression model:

$$
\mathrm{LS}_{\mathrm{it}}=\beta 0+\beta_{1} \mathrm{FSI}_{\mathrm{it}}+\beta_{\mathrm{x}} \mathrm{X}_{\mathrm{it}}+\mathrm{u}_{\mathrm{it}}
$$

where LS is life satisfaction in country $i$ at year $t$, FSI is food insecurity index, $X$ is a vector of control variables and $u$ is an error term. We estimate Equation (1) using several estimation techniques: ordinary least squares (OLS) regression, fixed effects (FE) estimator, generalized least squares (GLS) approach and instrumental variable two-stage least squares (IV 2SLS) method. The use of a wide range of methods allows us to take into account various problems that may be associated with the panel data: causality, unobserved characteristics and presence of influential observations. 


\section{Results}

The baseline results are reported in Table 2. Figure 1 reports the visual association between food insecurity and life satisfaction for the year 2019. As it can be seen, there is a strong negative correlation between food insecurity and subjective well-being.

Table 2. Main results: ordinary least squares (OLS) regression estimates.

\begin{tabular}{|c|c|c|c|c|c|c|c|}
\hline & $\mathbf{I}$ & II & III & IV & $\mathbf{V}$ & VI & VII \\
\hline \multirow[t]{2}{*}{ Food insecurity } & -0.055 & -0.056 & -0.056 & -0.055 & -0.054 & -0.051 & -0.052 \\
\hline & $(44.83)^{* * *}$ & $(42.65) * * *$ & $(36.60)^{* * *}$ & $(34.82)^{* * *}$ & $(33.37)^{* * *}$ & $(19.95)^{* * *}$ & $(20.12)^{* * *}$ \\
\hline \multirow[t]{2}{*}{ GDP growth } & & 0.018 & 0.016 & 0.018 & 0.017 & 0.015 & 0.017 \\
\hline & & $(2.16)^{* *}$ & -1.54 & $(1.71) *$ & -1.61 & -1.46 & -1.65 \\
\hline \multirow[t]{2}{*}{ Government size } & & & -0.001 & -0.002 & -0.007 & -0.009 & -0.007 \\
\hline & & & -0.12 & -0.41 & -1.3 & $(1.65) *$ & -1.28 \\
\hline \multirow[t]{2}{*}{ Democracy index } & & & & 0.012 & 0.01 & 0.008 & 0.008 \\
\hline & & & & $(2.67)^{* * *}$ & $(2.23)^{* *}$ & $(1.75) *$ & $(1.78) *$ \\
\hline \multirow{2}{*}{ Women in parliament } & & & & & 0.009 & 0.009 & 0.008 \\
\hline & & & & & $(3.40)^{* * *}$ & $(3.09) * * *$ & $(2.85) * * *$ \\
\hline \multirow[t]{2}{*}{ CPI } & & & & & & 0.004 & 0.002 \\
\hline & & & & & & $(1.75) *$ & -0.88 \\
\hline \multirow[t]{2}{*}{ Social capital } & & & & & & & 0.006 \\
\hline & & & & & & & $(2.94) * * *$ \\
\hline \multirow[t]{2}{*}{ Constant } & 7.806 & 7.785 & 7.795 & 7.713 & 7.558 & 7.33 & 7.159 \\
\hline & $(141.54)^{* * *}$ & $(139.44)^{* * *}$ & $(59.83) * * *$ & $(58.37)^{* * *}$ & $(52.58) * * *$ & $(34.99) * * *$ & $(32.36) * * *$ \\
\hline$R^{2}$ & 0.66 & 0.66 & 0.66 & 0.66 & 0.66 & 0.66 & 0.66 \\
\hline$N$ & 823 & 816 & 804 & 801 & 795 & 795 & 762 \\
\hline
\end{tabular}

Notes: $t$-statistics are reported in parentheses; food insecurity is the food insecurity index; GDP growth is annual GDP growth; government size is government final consumption expenditure as \% of GDP; CPI is corruption perception index; the control variables are lagged to reduce the effect of reverse causality ${ }^{*} p<0.1 ;{ }^{* *} p<0.05 ;{ }^{* * *} p<0.01$.

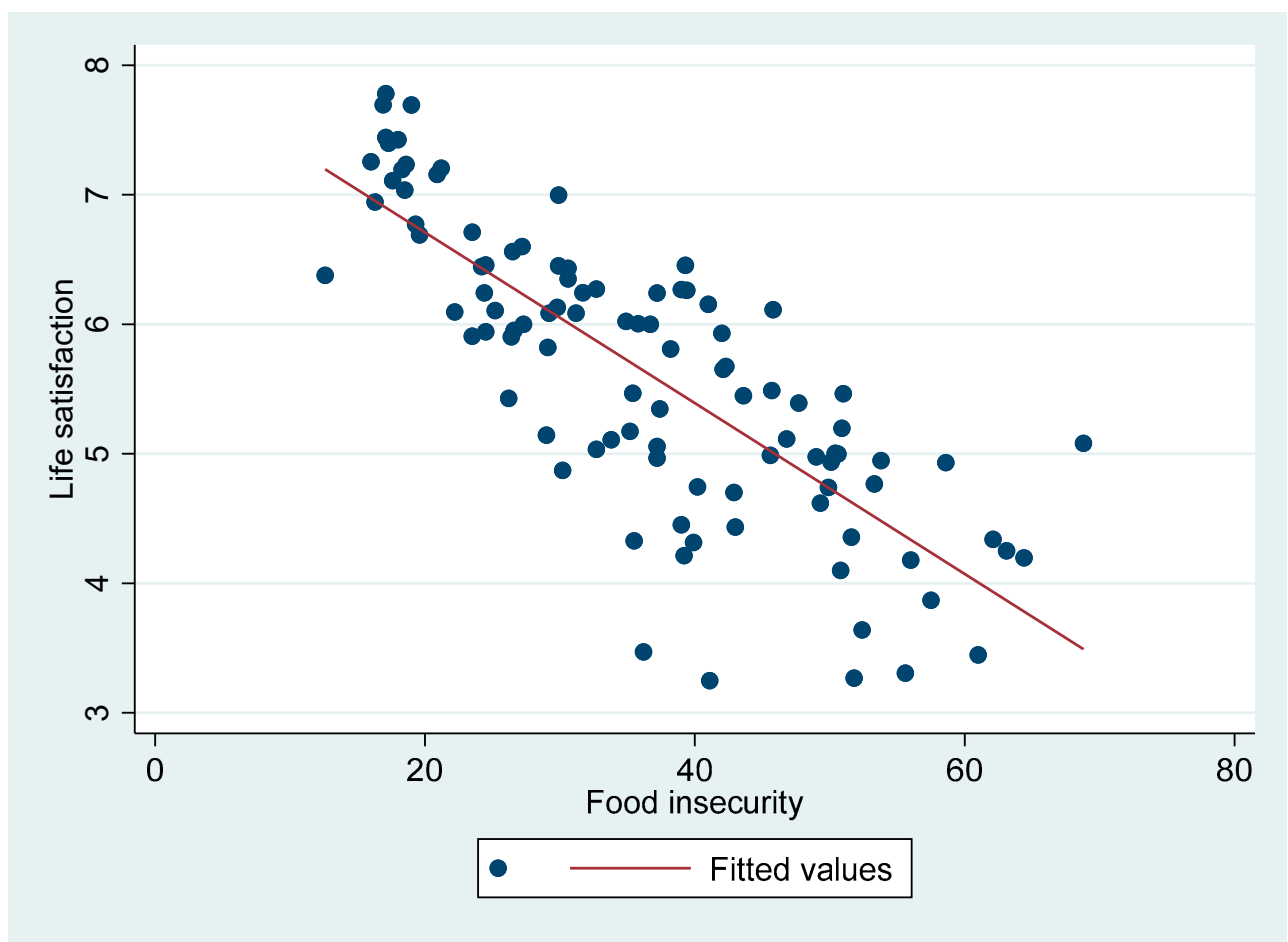

Figure 1. The scatterplot between food insecurity and life satisfaction.

Column 1 reports a bivariate association between food insecurity and life satisfaction. As anticipated, people in countries with higher levels of food insecurity risks are less likely to be satisfied with their lives. A one standard deviation increase in food insecurity index is associated with nearly one standard deviation decrease in life satisfaction index. We include GDP growth in column 2. As expected, GDP growth is positive and significant, 
while food insecurity retains its negative sign. We further include in a stepwise manner government size (column 3), democracy (column 4), women in parliament (column 5), CPI (column 6) and social capital (column 7). The coefficient for food insecurity is quantitatively and qualitatively not affected across all specifications. The results in Table 2 suggest that food insecurity is negatively associated with life satisfaction. Turning to control variables, the following noteworthy findings are discovered:

- In line with related literature, democracy is associated with higher levels of life satisfaction [32]. The capacity of a democratic government to deliver public services more efficiently is instrumental to increase subjective well-being [36].

- Greater political empowerment of women enhances life satisfaction. Indeed, research has shown that female parliamentarians are both directly and indirectly related to life satisfaction via education spending [37], welfare spending [38], quality of health [39] and others [40].

- $\quad$ Other things being the same, life satisfaction is higher in countries with higher levels of social capital, proxied by the proportion of the population that helps strangers. Moving from the country with the lowest to the highest levels of social capital, we see increases in life satisfaction by slightly less than a half-standard deviation.

- At the same time, we found that government size is insignificantly related to life satisfaction in our sample, which is similar to the correlations documented in Obydenkova and Salahodjaev [41].

On the other hand, Table 2 reports the preliminary results from pooled regression estimates. Therefore, the estimates may be affected by time trends, regional similarities and other aspects that are not captured by the mean regression estimator. We attempt to address these problems in Table 3. In column 1, we estimate Equation (1) by controlling for time and region fixed effects. For example, Figure 1 suggests that countries from the same region tend to be clustered together. The results suggest that the coefficient for food insecurity remains negative and significant, even though its quantitative effect has decreased. Apart from that, life satisfaction may be affected by unobserved characteristics across countries, such as historical legacies or geography, that could not be adequately captured by time-varying variables. Therefore, to address this problem we rely on fixed effects regression estimator. Finally, in column 3, we rely on the generalized least squares (GLS) estimator, as the data may suffer from heteroskedasticity or serial correlation. Again, food insecurity remains negative and significant across all methods applied in Table 3.

Another problem with the estimation techniques used above is the potential problem of endogeneity driven by omitted variable bias or reverse causality. In the mean regression analysis, we conjecture that food (in)security is the driving force of life (dis)satisfaction. However, other factors may influence both food insecurity and subjective well-being. For example, civil conflicts are correlated with both hunger and life satisfaction [42]. Related literature uses climate shocks and natural disasters as instruments for food insecurity $[8,43]$. For example, Niles and Salermo [44], using data from nearly 5300 households across 15 nations, found that those affected by natural disaster were 1.7 times more likely to report food insecurity. Smith and Frankenberger [4] reported that foods recorded in Bangladesh in 2014 had significant negative effect on household food security. Therefore, we use a proportion of the population affected by natural disasters (X1) and all damages and economic losses directly or indirectly related to the disaster as \% of GDP (X2). The data come from EM-DAT natural disasters dataset. We estimate a 2SLS regression and present the findings in Table 4. The first stage coefficients suggest that the proportion of the population affected by natural disasters positively and significantly predicts food insecurity, while economic costs of natural disasters is insignificant. The first stage F-statistics exceeds that threshold level of 10, suggesting that our instruments are correctly used in our empirical modeling. The second stage results further confirm the strength of our baseline results. If causal, a one standard deviation increase in instrumented food insecurity decreases life satisfaction by 0.8 points (slightly less than one standard deviation). Turning to the control variables, we found that democracy, representation of women in parliament and social capital are positively related 
to life satisfaction. At the same time, GDP growth, government size and corruption are insignificant in our model.

Table 3. Main results: fixed effects and generalized least squares estimates.

\begin{tabular}{cccc}
\hline & I & II & III \\
\hline Food insecurity & -0.027 & -0.014 & -0.047 \\
GDP growth & $(7.40)^{* * *}$ & $(2.71)^{* * *}$ & $(29.81)^{* * *}$ \\
& 0.024 & 0.029 & 0.009 \\
Government size & $(2.24)^{* *}$ & $(2.45)^{* *}$ & -1.54 \\
& 0.005 & -0.023 & -0.01 \\
Democracy index & -0.76 & -1.02 & $(2.85)^{* * *}$ \\
& -0.009 & -0.011 & 0.006 \\
Women in parliament & $(1.82)^{*}$ & -0.59 & $(1.90)^{*}$ \\
CPI & 0.005 & 0.001 & 0.01 \\
& $(1.97)^{* *}$ & -0.16 & $(6.95)^{* * *}$ \\
Social capital & 0.014 & 0.01 & 0.007 \\
Constant & $(6.74)^{* * *}$ & -1.56 & $(4.90)^{* * *}$ \\
$R^{2}$ & 0.012 & -0.001 & 0.005 \\
$N$ & $(6.00)^{* * *}$ & -0.41 & $(4.73)^{* * *}$ \\
Notes: & 5.358 & 6.064 & 6.816 \\
& $(20.44)^{* * *}$ & $(12.80)^{* * *}$ & $(48.98)^{* * *}$ \\
& 0.76 & 0.1 & 762 \\
& 762 & 762 & GLS \\
\hline
\end{tabular}

Notes: $t$-statistics are reported in parenthesis; food insecurity is the food insecurity index; GDP growth is annual GDP growth; government size is government final consumption expenditure as \% of GDP; CPI is corruption perception index; the control variables are lagged to reduce the effect of reverse causality ${ }^{*} p<0.1 ;{ }^{* *} p<0.05$; ${ }_{* * *} p<0.01$.

Table 4. Main results: instrumental variable two-stage least squares estimates.

\begin{tabular}{|c|c|c|}
\hline & I & II \\
\hline Food insecurity & $\begin{array}{c}-0.051 \\
(6.17)^{* * *}\end{array}$ & $\begin{array}{c}-0.045 \\
(2.35)^{* * *}\end{array}$ \\
\hline GDP growth & & $\begin{array}{l}0.012 \\
-0.68\end{array}$ \\
\hline Government size & & $\begin{array}{c}-0.004 \\
-0.37\end{array}$ \\
\hline Democracy index & & $\begin{array}{c}0.009 \\
(1.78)\end{array}$ \\
\hline Women in parliament & & $\begin{array}{c}0.008 \\
(2.65)^{* * *}\end{array}$ \\
\hline CPI & & $\begin{array}{r}0.006 \\
-0.53\end{array}$ \\
\hline Social capital & & $\begin{array}{c}0.005 \\
(2.08)^{* *}\end{array}$ \\
\hline Constant & $\begin{array}{c}7.648 \\
(22.07)^{* * * *}\end{array}$ & $\begin{array}{c}6.691 \\
(5.16)^{* * * *}\end{array}$ \\
\hline$R^{2}$ & 0.65 & 0.66 \\
\hline$N$ & $\begin{array}{c}823 \\
\text { Panel A: First stage } \\
\text { Dependent variable: FSI }\end{array}$ & 762 \\
\hline$X 1$ & $\begin{array}{c}95.837 \\
(4.49)^{* * *}\end{array}$ & $\begin{array}{c}41.847 \\
(3.42)^{* * *}\end{array}$ \\
\hline$X 2$ & $\begin{array}{c}-0.404 \\
-0.14\end{array}$ & $\begin{array}{c}-2.397 \\
-1.45\end{array}$ \\
\hline$R^{2}$ & 0.02 & 0.68 \\
\hline F-stat & 10.3 & 203.13 \\
\hline
\end{tabular}

Notes: $t$-statistics are reported in parenthesis; food insecurity is food insecurity index; GDP growth is annual GDP growth; government size is government final consumption expenditure as $\%$ of GDP; $\mathrm{CPI}$ is corruption perception index; the control variables are lagged to reduce the effect of reverse causality; $p<0.1 ;{ }^{* *} p<0.05 ;{ }^{* * *} p<0.01$ 
Finally, we revisit our main results reported in Table 2 for different regions in Table 5. We explore the relationship between food insecurity and life satisfaction for East Asia and Pacific (column 1), Europe and Central Asia (column 2), Latin America and Caribbean (column 3) and the rest of the world (column 4). Again, the results show that across various regions food security is negatively linked to life satisfaction.

Table 5. Robustness check: sub-regions.

\begin{tabular}{|c|c|c|c|c|}
\hline & I & II & III & IV \\
\hline \multirow{2}{*}{ Food insecurity } & -0.029 & -0.024 & -0.048 & -0.042 \\
\hline & $(3.52) * * *$ & $(4.02) * * *$ & $(7.04)^{* * *}$ & $(8.62) * * *$ \\
\hline \multirow{2}{*}{ GDP growth } & -0.093 & 0.054 & 0.058 & -0.008 \\
\hline & $(1.86) *$ & $(3.84)^{* * *}$ & $(2.97) * * *$ & -0.59 \\
\hline \multirow[t]{2}{*}{ Government size } & 0.009 & 0.014 & 0.027 & 0.004 \\
\hline & -0.67 & -1.39 & -1.45 & -0.52 \\
\hline \multirow[t]{2}{*}{ Democracy index } & 0.006 & -0.048 & 0.017 & -0.01 \\
\hline & -0.57 & $(5.23) * * *$ & -0.52 & -1.36 \\
\hline \multirow[t]{2}{*}{ Women in parliament } & 0.023 & 0.011 & 0.006 & -0.008 \\
\hline & $(2.33) * *$ & $(2.39) * *$ & $(1.84) *$ & $(2.38)^{* *}$ \\
\hline \multirow[t]{2}{*}{ CPI } & 0.004 & 0.026 & 0.002 & 0.005 \\
\hline & -0.54 & $(8.00) * * *$ & -0.45 & -0.93 \\
\hline \multirow[t]{2}{*}{ Social capital } & 0.01 & 0.008 & -0.001 & 0.004 \\
\hline & $(2.42)^{* *}$ & $(2.17)^{* *}$ & -0.12 & -1.13 \\
\hline \multirow[t]{2}{*}{ Constant } & 6.046 & 4.704 & 7.169 & 6.701 \\
\hline & $(10.00)^{* * *}$ & $(13.58)^{* * *}$ & $(12.74)^{* * *}$ & $(11.74)^{* * *}$ \\
\hline$R^{2}$ & 0.8 & 0.79 & 0.56 & 0.56 \\
\hline$N$ & 94 & 237 & 146 & 285 \\
\hline Regions & East Asia and Pacific & Europe and Central Asia & Latin America and Caribbean & Rest of the World \\
\hline
\end{tabular}

Notes: $t$-statistics are reported in parenthesis; food insecurity is the food insecurity index; GDP growth is annual GDP growth; government size is government final consumption expenditure as \% of GDP; CPI is corruption perception index. The control variables are lagged to reduce the effect of reverse causality; ${ }^{*} p<0.1 ;{ }^{* *} p<0.05 ;{ }^{* * *} p<0.01$.

\section{Conclusions}

We consider this study as a preliminary attempt to investigate the link between food insecurity and life satisfaction at a macro-social level, but further investigations in this area are required. Earlier studies have attempted to explore this relationship at the individual level using specific demographic groups. The data from 105 countries over the period 2012-2019, including food insecurity in life satisfaction regression, indicated that life satisfaction decreased with higher levels of food insecurity. Furthermore, resolving the problem of potential endogeneity of food insecurity, we further document that food insecurity has a causal negative effect on subjective well-being. In particular, a one standard deviation increase in instrumented food insecurity decreases life satisfaction by 0.8 points (slightly less than one standard deviation).

Moreover, our results show that improvements in gender equality, for example, in representation of women in parliament, also has a positive link to life satisfaction. Thus, improvements taking place in the agriculture sector of developing countries aimed at increasing food security should go along with improvements in gender equality. For example, increase in availability of agricultural credits for women, educational programs for female rural entrepreneurs and greater involvement of women in community management should have an effect not only on sustainable agriculture, but also on societal well-being.

Our findings further have a number of policy implications. First, the possible effect of food insecurity on life satisfaction can operate through the extension of the human capital framework, which has been documented in extant research. Food insecurity can affect various aspects of health outcomes [45], such as hypertension and diabetes [46]. For example, Jones [47], using data from 149 nations, found that food insecurity is related to poor mental health and specific psychosocial stressors. Therefore, improving the food security of households in developing countries is an important aspect to increasing not only subjective well-being, but also fostering human capital accumulation. In turn, this would have a positive effect on productivity. Second, policymakers should consider disaster 
preparedness and mitigation as a useful tool to reduce hunger risks and to improve life satisfaction. While natural disasters lead to greater migration and poverty, our results further suggest that natural disasters are causal to food insecurity and hunger across developed and developing countries. Therefore, the attainment of sustainable development agendas should take into account the negative consequences of natural disasters.

There are several ways our results could be extended by prospective studies. Our research has focused on the self-reported life satisfaction effects of food security. Apart from life satisfaction, food security may be an important antecedent of health outcomes at cross-country levels. Furthermore, it may be important to explore the link between food security and various human capital measures and Sustainable Development Goals.

Author Contributions: Conceptualization, Z.M. and R.S.; methodology, R.S.; software, R.S.; validation, Z.M. and R.S.; data curation, R.S.; writing-original draft preparation, R.S. and Z.M.; writingreview and editing, R.S. and Z.M. All authors have read and agreed to the published version of the manuscript

Funding: This research received no external funding.

Institutional Review Board Statement: Not applicable.

Informed Consent Statement: Not applicable.

Data Availability Statement: The data for the variables used in this study is available at respective agencies.

Conflicts of Interest: The authors declare no conflict of interest.

\section{References}

1. Battisti, D.S.; Naylor, R.L. Historical warnings of future food insecurity with unprecedented seasonal heat. Science 2009, 323, 240-244. [CrossRef]

2. De Haen, H.; Hemrich, G. The economics of natural disasters: Implications and challenges for food security. Agric. Econ. 2007, 37, 31-45. [CrossRef]

3. Diakosavvas, D. On the causes of food insecurity in less developed countries: An empirical evaluation. World Dev. 1989, 17, $223-235$. [CrossRef]

4. Smith, L.C.; Frankenberger, T.R. Does resilience capacity reduce the negative impact of shocks on household food security? Evidence from the 2014 floods in Northern Bangladesh. World Dev. 2018, 102, 358-376. [CrossRef]

5. Qi, X.; Vitousek, P.M.; Liu, L. Identification and evaluation of risk factors related to provincial food insecurity in China. J. Risk Res. 2015, 18, 1184-1202. [CrossRef]

6. Hendrix, C.; Brinkman, H.J. Food insecurity and conflict dynamics: Causal linkages and complex feedbacks. Stab. Int. J. Secur. Dev. 2013, 2, 2.

7. Warner, K.; Afifi, T. Where the rain falls: Evidence from 8 countries on how vulnerable households use migration to manage the risk of rainfall variability and food insecurity. Clim. Dev. 2014, 6, 1-17. [CrossRef]

8. Adelaja, A.; George, J.; Miyahara, T.; Penar, E. Food Insecurity and Terrorism. Appl. Econ. Perspect. Policy 2019, 41, 475-497. [CrossRef]

9. Smith, M.D.; Floro, M.S. Food insecurity, gender, and international migration in low- and middle-income countries. Food Policy 2020, 91, 101837. [CrossRef]

10. Koyanagi, A.; Stubbs, B.; Oh, H.; Veronese, N.; Smith, L.; Haro, J.M.; Vancampfort, D. Food insecurity (hunger) and suicide attempts among 179,771 adolescents attending school from 9 high-income, 31 middle-income, and 4 low-income countries: A cross-sectional study. J. Affect. Disord. 2019, 248, 91-98. [CrossRef]

11. Russell, J.C.; Flood, V.M.; Yeatman, H.; Wang, J.J.; Mitchell, P. Food insecurity and poor diet quality are associated with reduced quality of life in older adults. Nutr. Diet. 2016, 73, 50-58. [CrossRef]

12. Hadley, C.; Patil, C.L. Seasonal changes in household food insecurity and symptoms of anxiety and depression. Am. J. Phys. Anthropol. 2008, 135, 225-232. [CrossRef] [PubMed]

13. Diener, E.; Oishi, S. Are Scandinavians happier than Asians? Issues on comparing nations on subjective wellbeing. In Asian Economic and Political Issues, 10th ed.; Columbus, F., Ed.; Nova Science: Hauppauge, NY, USA, 2004.

14. Willows, N.; Veugelers, P.; Raine, K.; Kuhle, S. Associations between household food insecurity and health outcomes in the Aboriginal population (excluding reserves). Health Rep. 2011, 22, 15. [PubMed]

15. Asfahani, F.; Kadiyala, S.; Ghattas, H. Food Insecurity and Subjective Wellbeing Among Arab Youth Living in Varying Contexts of Political Instability. J. Adolesc. Health 2019, 64, 70-78. [CrossRef]

16. Patel, K.; Gartaula, H.; Johnson, D.; Karthikeyan, M. The interplay between household food security and wellbeing among small-scale farmers in the context of rapid agrarian change in India. Agric. Food Secur. 2015, 4, 16. [CrossRef] 
17. Pourmotabbed, A.; Moradi, S.; Babaei, A.; Ghavami, A.; Mohammadi, H.; Jalili, C.; Miraghajani, M. Food insecurity and mental health: A systematic review and meta-analysis. Public Health Nutr. 2020, 23, 1778-1790. [CrossRef] [PubMed]

18. Hadley, C.; Patil, C.L. Food insecurity in rural Tanzania is associated with maternal anxiety and depression. Am. J. Hum. Biol. 2006, 18, 359-368. [CrossRef]

19. Huddleston-Casas, C.; Charnigo, R.; Simmons, L.A. Food insecurity and maternal depression in rural, low-income families: A longitudinal investigation. Public Health Nutr. 2009, 12, 1133-1140. [CrossRef]

20. Kaiser, L.; Baumrind, N.; Dumbauld, S. Who is food-insecure in California? Findings from the California Women's Health Survey, 2004. Public Health Nutr. 2007, 10, 574-581. [CrossRef]

21. Chilton, M.; Booth, S. Hunger of the body and hunger of the mind: African American women's perceptions of food insecurity, health and violence. J. Nutr. Educ. Behav. 2007, 39, 116-125. [CrossRef]

22. Pinard, C.A.; Calloway, E.E.; Fricke, H.E.; Yaroch, A.L. A cross-sectional exploration of food security, depression, and CHAOS in low-income households with children. J. Appl. Res. Child. Inf. Policy Child. Risk 2015, 6, 6.

23. Frongillo, E.A.; Nguyen, H.T.; Smith, M.D.; Coleman-Jensen, A. Food insecurity is associated with subjective well-being among individuals from 138 countries in the 2014 Gallup World Poll. J. Nutr. 2017, 147, 680-687. [CrossRef]

24. Layard, R. Measuring subjective well-being. Science 2010, 327, 534-535. [CrossRef]

25. Kahneman, D.; Krueger, A.B.; Schkade, D.A.; Schwarz, N.; Stone, A.A. A survey method for characterizing daily life experience: The day reconstruction method. Science 2004, 306, 1776-1780. [CrossRef]

26. Andrews, F.M.; Withey, S.B. Social Indicators of Well-Being: Americans' Perceptions of Life Quality; Springer Science \& Business Media: Berlin/Heidelberg, Germany, 2012.

27. Kammann, R.; Flett, R. Affectometer 2: A scale to measure current level of general happiness. Aust. J. Psychol. 1983, 35, $259-265$. [CrossRef]

28. Dolan, P.; Metcalfe, R. Measuring subjective wellbeing: Recommendations on measures for use by national governments. J. Soc. Policy 2012, 41, 409-427. [CrossRef]

29. Helliwell, J.F.; Layard, R.; Sachs, J.; De Neve, J. World Happiness Report 2020; Sustainable Development Solutions Network: New York, NY, USA, 2020.

30. Barrett, C.B. Measuring food insecurity. Science 2010, 327, 825-828. [CrossRef] [PubMed]

31. Kollamparambil, U. Happiness, happiness inequality and income dynamics in South Africa. J. Happiness Stud. 2020, 21, 201-222. [CrossRef]

32. Loubser, R.; Steenekamp, C. Democracy, well-being, and happiness: A 10-nation study. J. Public Aff. 2017, 17, e1646. [CrossRef]

33. Bjørnskov, C.; Dreher, A.; Fischer, J.A. The bigger the better? Evidence of the effect of government size on life satisfaction around the world. Public Choice 2007, 130, 267-292. [CrossRef]

34. Elgar, F.J.; Davis, C.G.; Wohl, M.J.; Trites, S.J.; Zelenski, J.M.; Martin, M.S. Social capital, health and life satisfaction in 50 countries. Health Place 2011, 17, 1044-1053. [CrossRef]

35. Salahodjaev, R.; Abdullaeva, B.; Tosheva, S.; Isaeva, A. Female Parliamentarians and the Distribution of National Happiness. Appl. Res. Qual. Life 2020, 1-15. [CrossRef]

36. Orviska, M.; Caplanova, A.; Hudson, J. The impact of democracy on well-being. Soc. Indic. Res. 2014, 115, 493-508. [CrossRef]

37. Chen, L.J. Female policymakers and educational expenditures: Cross-country evidence. Eur. J. Law Econ. 2020, 1-27. [CrossRef]

38. Park, S.S. Gendered representation and critical mass: Women's legislative representation and social spending in 22 OECD countries. Sociol. Perspect. 2017, 60, 1097-1114. [CrossRef]

39. Swiss, L.; Fallon, K.M.; Burgos, G. Does critical mass matter? Women's political representation and child health in developing countries. Soc. Forces 2012, 91, 531-558. [CrossRef]

40. Salahodjaev, R.; Jarilkapova, D. Women in parliament and deforestation: Cross-country evidence. J. Nat. Conserv. 2020, 55, 125830. [CrossRef]

41. Obydenkova, A.V.; Salahodjaev, R. Government size, intelligence and life satisfaction. Intelligence 2017, 61, 85-91. [CrossRef]

42. Welsch, H. The social costs of civil conflict: Evidence from surveys of happiness. Kyklos 2008, 61, 320-340. [CrossRef]

43. Demeke, A.B.; Keil, A.; Zeller, M. Using panel data to estimate the effect of rainfall shocks on smallholders food security and vulnerability in rural Ethiopia. Clim. Chang. 2011, 108, 185-206. [CrossRef]

44. Niles, M.T.; Salerno, J.D. A cross-country analysis of climate shocks and smallholder food insecurity. PLoS ONE 2018, 13, e0192928.

45. Gundersen, C.; Ziliak, J.P. Food insecurity and health outcomes. Health Aff. 2015, 34, 1830-1839. [CrossRef]

46. Wang, E.A.; McGinnis, K.A.; Goulet, J.; Bryant, K.; Gibert, C.; Leaf, D.A.; Fiellin, D.A. Food insecurity and health: Data from the Veterans Aging Cohort Study. Public Health Rep. 2015, 130, 261-268. [CrossRef] [PubMed]

47. Jones, A.D. Food insecurity and mental health status: A global analysis of 149 countries. Am. J. Prev. Med. 2017, 53, 264-273. [CrossRef] [PubMed] 